\title{
LABORATORY EVALUATION OF THE DEVELOPMENT OF Aedes aegypti IN TWO SEASONS: INFLUENCE OF DIFFERENT PLACES AND DIFFERENT DENSITIES
}

\author{
Tatiana Forte LOPES, Marcia Moreira HOLCMAN, Gerson Laurindo BARBOSA, Maria de Fatima DOMINGOS \& Rosa Maria Oliveira Veiga BARREIROS
}

\begin{abstract}
SUMMARY
Aedes aegypti is an important vector in Brazil being the main vector of the dengue-fever. This paper employs survival curves to describe the time in days from larvae to adult forms of Aedes aegypti raised, individually and collectively, and compares it during winter and spring when positioned inside and outside a laboratory. The study was conducted in São Vicente, a coastal city in Southeastern Brazil. The lowest water temperature in winter and in spring was $20^{\circ} \mathrm{C}$ and the highest was $26^{\circ} \mathrm{C}$ in spring. Higher and more stable temperatures were measured in the intra compared to the peri in both seasons. Consequently, larvae positioned in the intra resulted in the lowest median time to develop in the individual and collective experiment (nine and ten days, respectively). At least $25 \%$ of the larvae positioned in the intra in the individual experiment in the spring took only seven days to reach adulthood. Sex ratios and the median time development by sex did not show significant differences. These results indicate that efforts to control Aedes aegypti must be continuous and directed mainly to prevent the intra-domiciliary sites that can be infested in a week in order to reduce the human-vector contact.
\end{abstract}

KEYWORDS: Aedes aegypti; Development time; Temperature; Survival analysis.

\section{INTRODUCTION}

Aedes (Stegomya) aegypti (L.) is one of the most important vectors in Brazil, as the main vector of urban yellow fever and dengue fever. The World Health Organization estimates that 50 to 100 million people are infected annually and 2.5 billion people are living in places at risk of acquiring dengue in the World ${ }^{28}$. In 2011, according to the Pan American Health Organization, 64\% of the fatal cases of dengue in South America were from Brazil ${ }^{21}$. At the present time, dengue fever is the most important infectious disease in Brazil ${ }^{25}$.

The Aedes aegypti is usually found between latitudes $45^{\circ} \mathrm{N}$ and $35^{\circ}$ $\mathrm{S}$, and less frequent at altitudes of more than 1,000 meters due to low temperatures in these places ${ }^{14}$. Its distribution is directly associated to human activities because of the availability of a great variety of artificial containers used by modern society that are usually employed as breeding sites. These containers are responsible for the maintenance of great populations of the vector and consequently favor the interaction between man and vector ${ }^{16,24}$.

In Brazil, this species was introduced with the colonization and the first outbreak of yellow fever occurred in 1685 in Recife-PE ${ }^{15}$. In 1958, after several campaigns undertaken to eradicate the vector, the species was considered as eliminated. After that, the vector alternated periods of elimination and reintroduction and is currently present in all regions of Brazil ${ }^{4}$.
Temperature is one of the main ecological factors associated with its development and feeding habits ${ }^{13,23}$. BESERRA et al. (2006) studying the life cycle of the Aedes aegypti at four different temperatures reported that temperatures between $21^{\circ} \mathrm{C}$ and $29^{\circ} \mathrm{C}$ were the most favorable for its development and FARNESI et al. (2009) observed that low $\left(16^{\circ} \mathrm{C}\right)$ or very high $\left(36^{\circ} \mathrm{C}\right)$ temperatures act as a limiting factor regarding development and population growth. According to YANG et al. (2009), studying the effects of temperature on the Aedes aegypti population concluded that the temperature range from $15^{\circ} \mathrm{C}$ to $30^{\circ} \mathrm{C}$ was suitable for survival of adult mosquitoes while the range from $15^{\circ} \mathrm{C}$ to $35^{\circ} \mathrm{C}$ was optimal for the aquatic stages. Likewise, daily temperature differences can affect their competence to transmit the virus in infected mosquitoes ${ }^{6,7,18}$. So, the knowledge of the effects of the temperature in the life cycle of the Aedes aegypti is an important issue to consider in the surveillance and control programs $^{2}$. This paper aims to describe the duration of development of the Aedes aegypti during winter and spring and compare it when positioned in places inside and outside buildings.

\section{MATERIAL AND METHODS}

It is an experimental study conducted in the Laboratory of the Regional Service of the Superintendencia de Controle de Endemias/Sucen located in the coastal city of São Vicente in the São Paulo State situated in

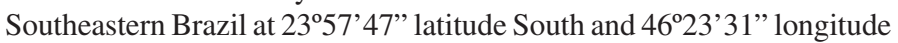
West. The city has approximately 332,000 inhabitants, characterized by tropical rainy climate with no dry season and an average rainfall in the 


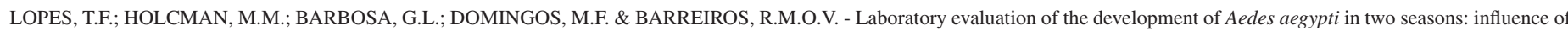
different places and different densities. Rev. Inst. Med. Trop. Sao Paulo, 56(5): 369-74, 2014

driest month exceeding $60 \mathrm{~mm}^{(8)}$. The Aedes aegypti was first reported in 1995 in São Vicente and the municipality has been reporting dengue cases since $1997^{11}$.

The study was conducted in 2008 in two seasons of the year, the first in winter (starting at 15/08/2008 and finishing at 05/09/2008) ) and the second in the spring (starting at 29/11/2008 and finishing at 22/12/2008). The strain of the Aedes aegypti employed was originated from field collection in the city of Santos, second generation (F2). The eggs were placed in strips of filter paper inside white plastic bowls containing $400 \mathrm{~mL}$ of water and monitored daily to verify hatching larvae. The recent hatched larvae were reared in two different densities, individually (only one larva) into glass jars of $15 \mathrm{~mL}$ containing $5 \mathrm{~mL}$ of water and collectively (50 larvae) in plastic bowls containing $250 \mathrm{~mL}$ of water. In each season the individual experiment consisted of observing a group of 60 jars, 30 placed inside the laboratory (intra) and the other 30 placed outside (peri) in a place protected from the rain. In the same way, the collective experiment consisted of the observation of four plastic bowls each containing 50 larvae, two placed intra and the other two placed peri. These four treatments were held in order to simulate some of the possible conditions of the life cycle of the vector in urban areas in two seasons of the year.

The larvae were fed with a mixture of $0.05 \mathrm{~g}$ of macerated fish food diluted with $400 \mathrm{~mL}$ of water from the public water supply. Every two days, $5 \mathrm{~mL}$ and $150 \mathrm{~mL}$ of the mixture was added in the individual observation jars and in the bowls of the collective observations, respectively.

Each individual glass jar was monitored daily, in order to identify the presence of exuviae that denotes the change to the pupa stage. When the pupa stage was achieved, the glasses were covered with a punctured plastic bag to allow the transition to adult form. Equally, the collective experiment was monitored daily and when individuals pupated they were transferred to a glass recipient of $500 \mathrm{~mL}$ containing $200 \mathrm{~mL}$ of water, these glasses were sealed with a plastic punctured bag to allow the transition to adult form.

The water temperature was registered daily in the intra and peri places. The length of time in days elapsed from newly hatched larvae to the adult form and the sex of the specimens were registered for all the treatments.

The Kruskal-Wallis one way analysis of variance by ranks test was used to compare the medians of the water temperature in the four treatments. The multiple comparison tests using a significance level adjusted to the number of possible comparisons and the differences of the average ranks were used to identify the paired differences among the four groups ${ }^{22}$. The chi-square test was used to compare proportions. The Kaplan-Meier estimates were used to analyze time in days from newly hatched larvae to adult form by type of experiment (individual and collective), stratified by place (intra and peri) and season of the year (winter and spring) and these survival curves were compared using the log-rank test ${ }^{9}$. All statistical tests were performed using the value of $\alpha=0.05$ significance levels and all tests with $p$-value less than 0.05 were considered as significant.

\section{RESULTS}

Of the 400 newly hatched larvae in the collective experiment, 360
(90\%) reached adulthood. In the winter, this proportion was smaller $(84 \% ; 168 / 200)($ chi-square $=16.00 ; \mathrm{DF}=1 ; p<0.00001)$ than in the spring $(96 \% ; 192 / 200)$. In the winter, the losses were greater in the peri $(29 \% ; 71 / 100)$ than in the intra $(3 \% ; 97 / 100)($ chi-square $=25.15 ; \mathrm{DF}$ $=1 ; p<0.0001)$. In the spring, the losses by place $(5 \%$ in the peri and $3 \%$ in the intra) were equal (chi-square $=0.52 ; \mathrm{DF}=1 ; p=0.470$ ). In the individual experiment, from the 120 glasses observed, 115 (95.8\%) reached adulthood and no significant differences were observed between the losses by season or by place.

The smallest temperature $\left(20^{\circ} \mathrm{C}\right)$ was measured in the winter in the peri and the highest $\left(26^{\circ} \mathrm{C}\right)$ was measured in the spring in the intra. In general higher temperatures were measured in the intra compared to the peri and the variation of temperature was greater in the peri (Fig. 1). There was a statistically significant difference between, at least, one of the four treatments (chi-square $=21.467 ; \mathrm{DF}=3 ; p=0.0001$ ). The paired comparisons between the temperatures measured in Winter/peri and Spring/intra treatments and between Spring/peri and Spring/intra treatments have been statistically significant.

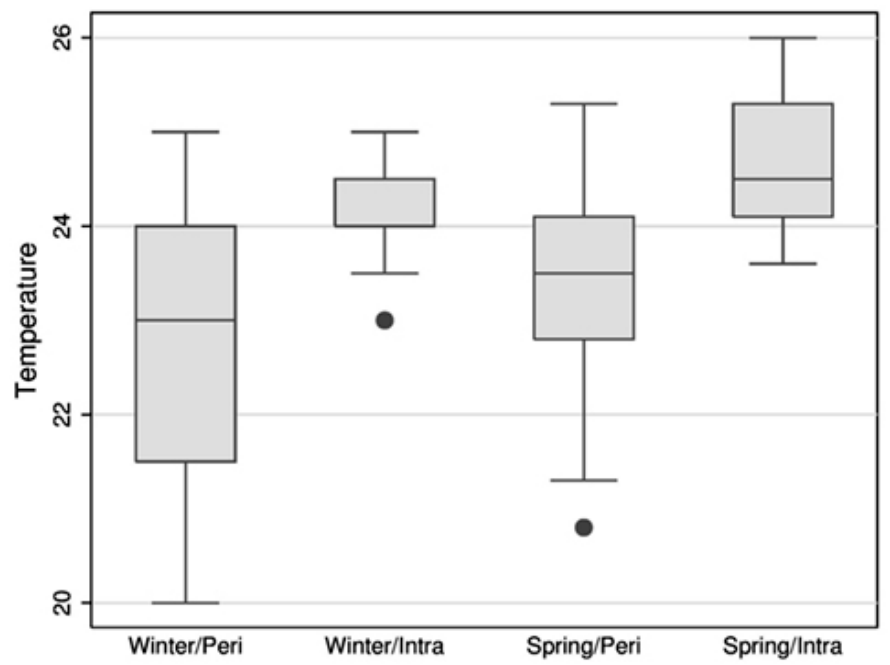

Fig. 1 - Box Plot of water temperature by season and place, São Vicente, SP, 2008

In general, the median time from larvae to adult was smaller in the individual experiment. Furthermore, lower median times of development were achieved in spring in the intra in both individual (nine days) and collective (ten days) experiments compared to the other treatments ( $p<$ 0.001 ). The minimum time of development (seven days) was achieved by $25 \%$ of the larvae in spring in the individual treatment placed intra (Fig. 2).

Overall the proportion of males emerged $(56.63 \% ; 269 / 475)$ was greater than females $(\mathrm{z}=2.86 ; p=0.04)$. Considering each treatment most of the sex ratios obtained showed no significant difference, except for spring in the collective experiment (chi-square $=4.26 ; \mathrm{DF}=1$; $p=0.0391$ ) (Table 1).

The median time from larvae to adult development in the males was smaller than the females except from the individual density in the spring/ peri treatment (chi-square $=6.3 ; \mathrm{DF}=1 ; p=0.0122$ ). The estimated curves differed significantly between sexes according to the log-rank test 

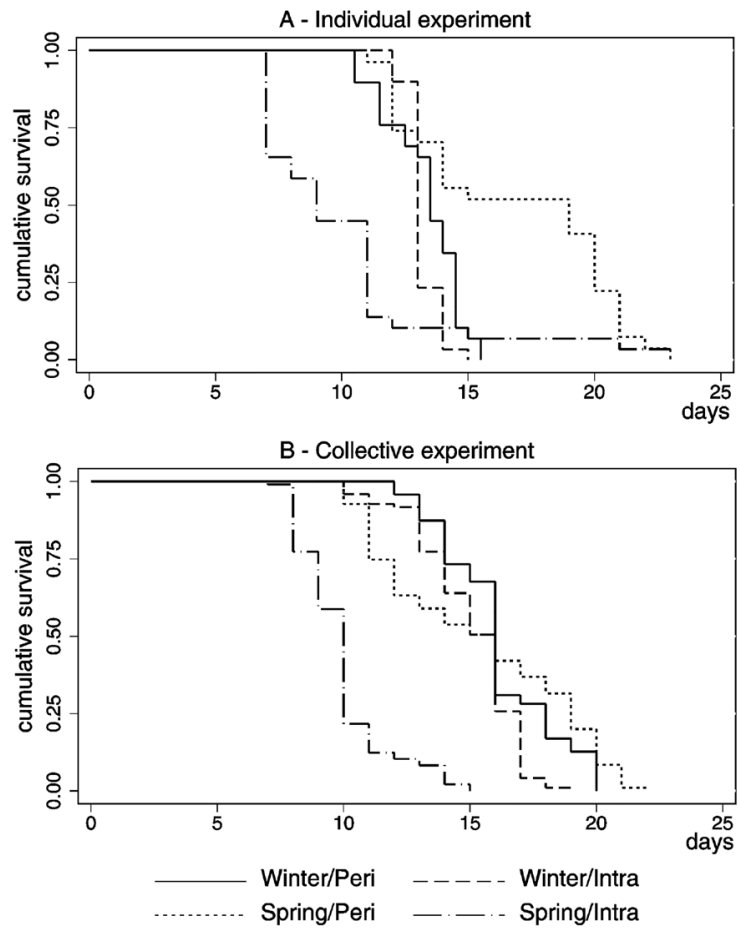

Fig. 2 - Kaplan-Meier survival plot for Aedes aegypti development by type of experiment, season and local, São Vicente, SP, 2008.

in the individual experiment in the winter/peri treatment (chi-square $=$ 26.0; $\mathrm{DF}=1 ; p=0.0150$ ) and in the spring/peri treatments (chi-square $=6.28 ; \mathrm{DF}=1 ; p=0.0122)$. In the collective experiment the estimated curves differed significantly in the winter/intra treatment (chi-square $=$ 26.0; $\mathrm{DF}=1 ; p<0.0001)$ and in the spring/intra treatment (chi-square $=4.3 ; \mathrm{DF}=1 ; p=0.0383$ ) (Fig. 3).

\section{DISCUSSION}

The aim of this study was to simulate the natural conditions of development of the Aedes aegypti vector in the urban environment in a laboratory in a tropical climate municipality. The smallest period (seven days) of development was achieved by larvae reared individually inside the laboratory and the largest time ( 22 days) was accomplished by the larvae reared collectively outside the laboratory.

The feasibility of the eggs and period of development in this study was similar to other experiments conducted at temperatures above $20^{\circ} \mathrm{C}^{2,5,10,16}$. The specimens raised in the intra where the temperature was higher than the peri places resulted in a shorter period of development of the larvae. These results agree with other studies ${ }^{2,3,5,10,26}$, in which the temperature was inversely proportional to the period of development.

Some of the larvae placed Intra in the spring simulating the possibility of finding the vector inside households in a protected place had the lowest time to develop (seven days), indicating the risk of infestation in only a few days. These outcomes are similar to the results obtained by TUN-LIN et al. (2000) in two Australian cities where the containers classified as exposed were more likely to increase the duration of the period of development. On the other hand, another study performed in two neighborhoods in the city of Rio de Janeiro, reported controversial results, at one site the pupae productivity was greater in containers placed in the sunlight, while in the other site shaded areas had more productivity ${ }^{19}$.

The individual experiment resulted in lower periods of development, suggesting the existence of density dependence between larvae. Similar results were found in other experiments where larvae in isolated areas pupated earlier, and experiments with higher larval densities resulted in higher mortality or vectors with smaller wings ${ }^{1,17,27}$.

The proportion of males was higher than females although without significance. In most of the treatments, the same results were achieved by

Table 1

Number and proportion of Aedes aegypti by type of experiment, season, location and sex, São Vicente-SP, 2008

\begin{tabular}{|c|c|c|c|c|c|c|c|c|c|}
\hline \multirow{2}{*}{$\begin{array}{l}\text { Type of expe- } \\
\text { riment }\end{array}$} & \multirow{2}{*}{ Season } & \multirow{2}{*}{ Local } & \multicolumn{2}{|c|}{ Female } & \multicolumn{2}{|c|}{ Male } & \multicolumn{2}{|c|}{ Total } & \multirow{2}{*}{$p^{*}$} \\
\hline & & & $\mathrm{N}$ & $\%$ & $\mathrm{~N}$ & $\%$ & $\mathrm{~N}$ & $\%$ & \\
\hline \multirow{6}{*}{ Individual } & \multirow{3}{*}{ winter } & Peri & 11 & 37.9 & 18 & 62.1 & 29 & 100.0 & 0.351 \\
\hline & & Intra & 15 & 50.0 & 15 & 50.0 & 30 & 100.0 & \\
\hline & & Total & 26 & 44.1 & 33 & 55.9 & 59 & 100.0 & \\
\hline & \multirow{3}{*}{ spring } & Peri & 7 & 25.9 & 20 & 74.1 & 27 & 100.0 & 0.672 \\
\hline & & Intra & 9 & 31.0 & 20 & 69.0 & 29 & 100.0 & \\
\hline & & Total & 16 & 28.6 & 40 & 71.4 & 56 & 100.0 & \\
\hline \multirow{6}{*}{ Collective } & \multirow{3}{*}{ winter } & Peri & 42 & 59.2 & 29 & 40.8 & 71 & 100.0 & 0.560 \\
\hline & & Intra & 53 & 54.6 & 44 & 45.4 & 97 & 100.0 & \\
\hline & & Total & 95 & 56.5 & 73 & 43.5 & 168 & 100.0 & \\
\hline & \multirow{3}{*}{ spring } & Peri & 41 & 43.2 & 54 & 56.8 & 95 & 100.0 & 0.039 \\
\hline & & Intra & 28 & 28.9 & 69 & 71.1 & 97 & 100.0 & \\
\hline & & Total & 69 & 35.9 & 123 & 64.1 & 192 & 100.0 & \\
\hline
\end{tabular}

${ }^{*} p$ value of the chi-square test with one degree of freedom. 


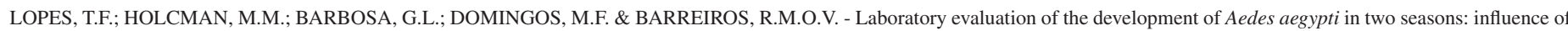
different places and different densities. Rev. Inst. Med. Trop. Sao Paulo, 56(5): 369-74, 2014.
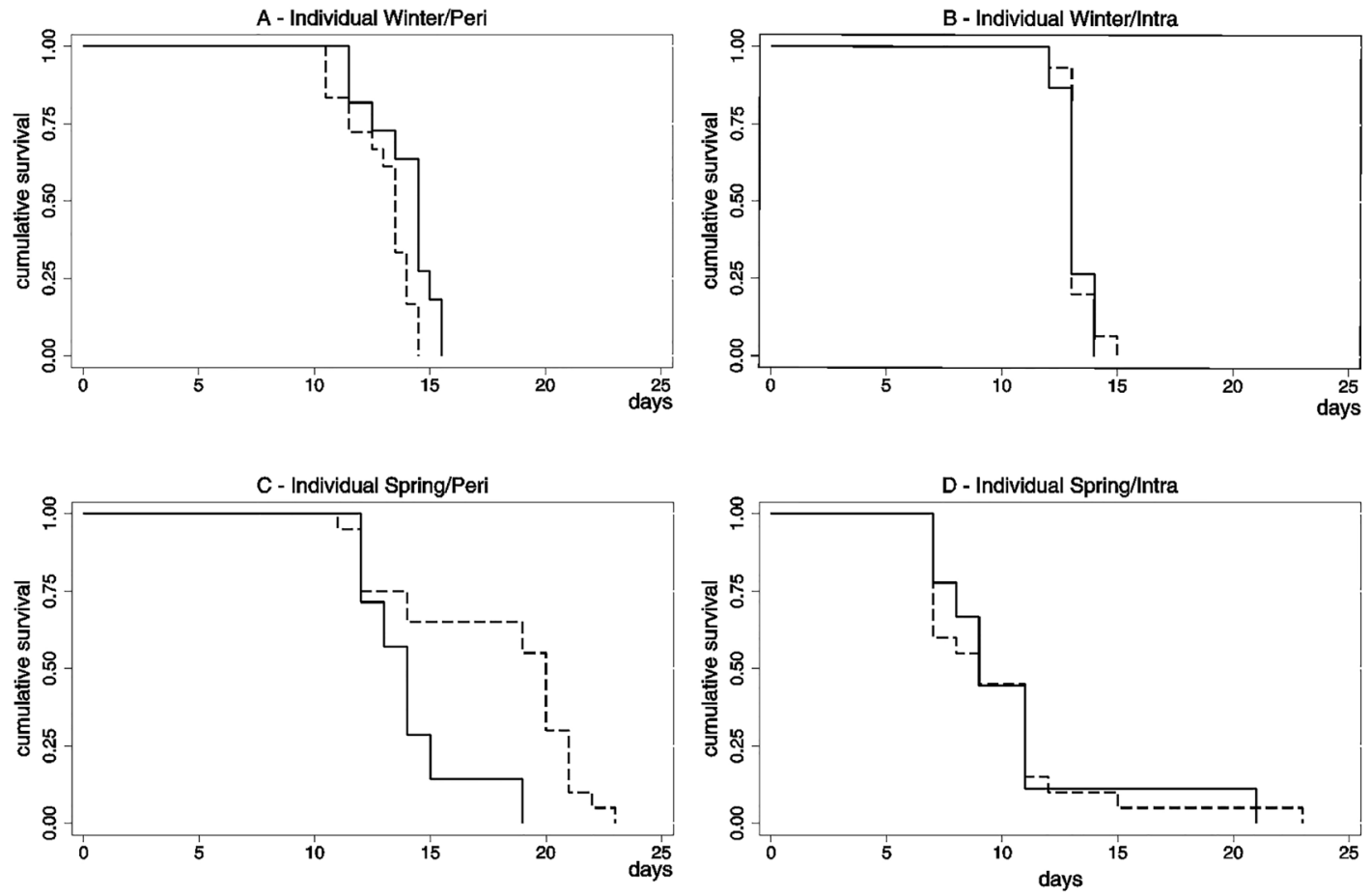

Female - - - Male

Fig. 3 - Kaplan-Meier survival plot for Aedes aegypti development of the individual experiment by season, local and sex, São Vicente, SP, 2008.
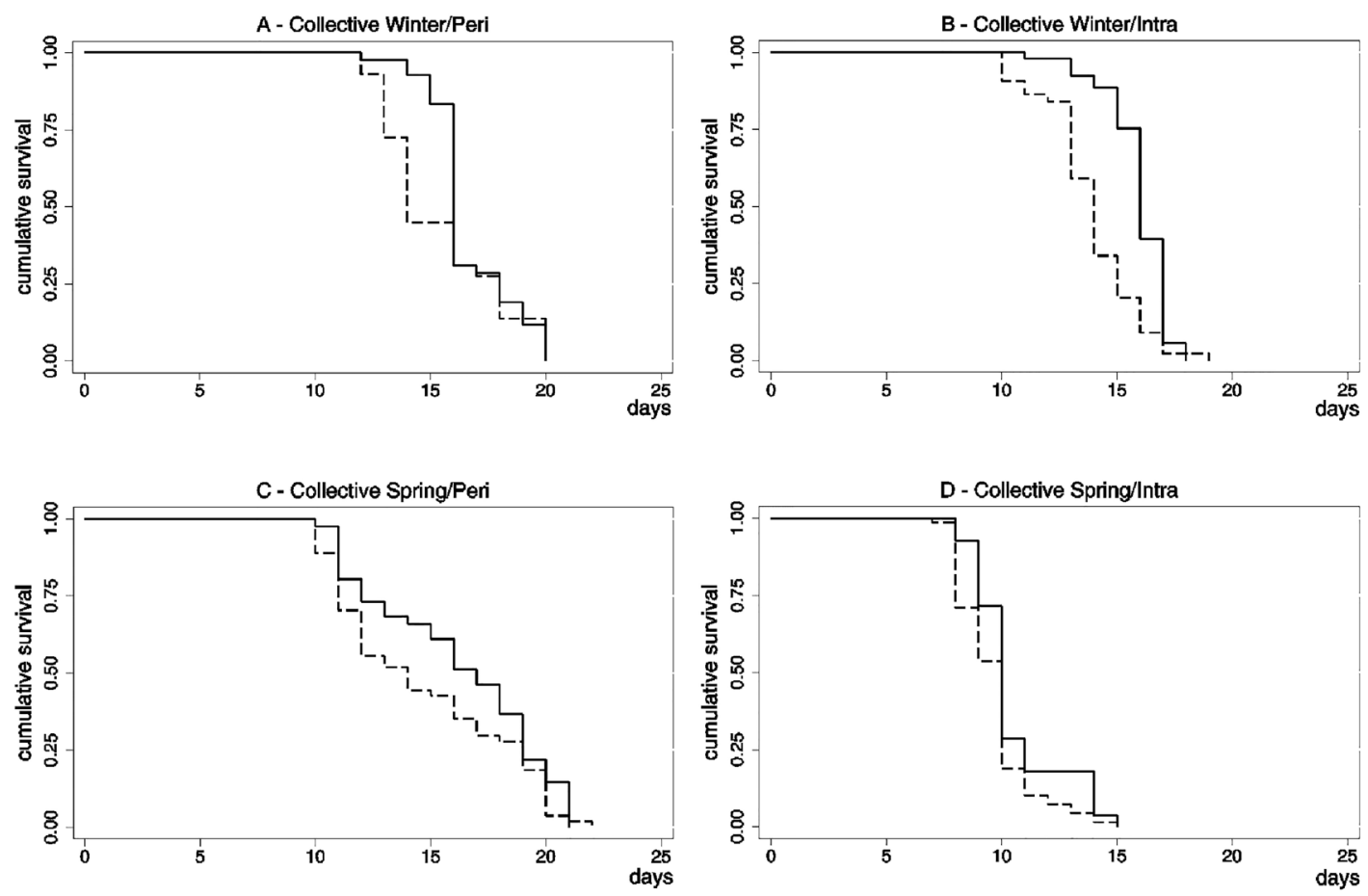

Female

Male

Fig. 4 - Kaplan-Meier survival plot for Aedes aegypti development of the collective experiment by season, local and sex, São Vicente, SP, 2008. 


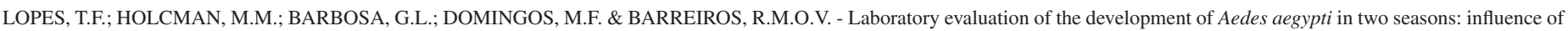
different places and different densities. Rev. Inst. Med. Trop. Sao Paulo, 56(5): 369-74, 2014.

other studies where the temperature did not affect the sex proportion ${ }^{5,10,20}$. In general, the period of development of males was shorter than females during the treatments. This result is similar to that reported by another study where the male development was shorter compared to females ${ }^{1}$.

In this study, other factors that could modify the conditions of development of Aedes aegypti such as accumulated precipitation and evaporation of water were not measured, representing a possible constraint of the results.

The study was performed in a location where the median temperature remained higher than $20^{\circ} \mathrm{C}$ during the experiment, suiting the appropriate temperature required for vector development ${ }^{29}$, even so, the period of development of the Aedes aegypti was influenced by the variation of temperature in the experiment. Other studies highlighted the influence of the pattern of variability and amplitude of the temperature in vector competence and vector survival ${ }^{6,18}$. Even though the relationship among vector productivity and dengue are not direct since it does not account for other factors related to the disease, like the virus circulation or the host immune system, the amount of vectors and their adaptation capacity play an important role in the transmission dynamics ${ }^{25}$. So these results indicate that the efforts to control Aedes aegypti inside homes must be continuous to prevent infestation and reduce the human-vector contact to achieve a dengue infection control.

\section{RESUMO}

\section{A avaliação do desenvolvimento do Aedes aegypti em duas estações do ano: influência de diferentes locais e densidades}

Foram utilizadas curvas de sobrevida para analisar o tempo de desenvolvimento do Aedes aegypti, principal vetor da dengue no Brasil. Foram comparadas as curvas de sobrevida dos vetores criados individualmente e coletivamente quando posicionados dentro e fora do laboratório no inverno e na primavera. O estudo foi realizado em São Vicente, cidade costeira do sudeste do Brasil. A temperatura mínima da água atingiu $20{ }^{\circ} \mathrm{C}$ no inverno e na primavera, e a máxima $26{ }^{\circ} \mathrm{C}$ na primavera. As temperaturas mais elevadas e estáveis foram medidas dentro do laboratório em comparação com as medidas fora em ambas as estações. Consequentemente as larvas posicionadas dentro apresentaram menor tempo mediano de desenvolvimento no experimento individual e coletivo (nove e dez dias, respectivamente). Pelo menos $25 \%$ das larvas criadas individualmente dentro do laboratório levaram apenas sete dias para atingir a forma adulta. As proporções macho/fêmea e o tempo de desenvolvimento por sexo não diferiu significativamente. Estes resultados indicam que as medidas para controlar o Aedes aegypti e reduzir o contato humano com o vetor devem ser contínuas e dirigidas, principalmente para os locais dentro dos domicílios uma vez que o ciclo do vetor pode durar apenas uma semana nestes locais.

\section{REFERENCES}

1. Agnew P, Hide M, Sidobre C, Michalakis Y. A minimalist approach to the effects of density-dependent competition on insect life-history traits. Ecol Entomol. 2002;27:396-402.

2. Beserra EB, Castro FP Jr, Santos JW, Santos TS, Fernandes CRM. Biologia e exigências térmicas de Aedes aegypti (L.) (Diptera: Culicidae) provenientes de quatro regiões bioclimáticas da Paraíba. Neotrop Entomol. 2006;35:853-60.
3. Beserra EB, Castro FP Jr. Biologia comparada de populações de Aedes (Stegomyia) aegypti (L.) (Diptera Culicidae) da Paraiba. Neotrop Entomol. 2008;37:81-5.

4. Braga IA, Valle D. Aedes Aegypti: histórico do controle no Brasil. Epidemiol Serv Saúde. 2007; $16: 113-8$

5. Calado DC, Silva MAN. Avaliação da influência da temperatura sobre o desenvolvimento de Aedes albopictus. Rev Saúde Pública. 2002;36:173-9.

6. Carrington LB, Armijos MV, Lambrechts L, Scott TW. Fluctuations at a low mean temperature accelerate dengue virus transmission by Aedes aegypti. PLOS Negl Trop Dis. 2013;7:e2190.

7. Carrington LB, Armijos MV, Lambrechts L, Barker CM, Scott TW. Effects of fluctuating daily temperatures at critical thermal extremes on Aedes aegypti life-history traits. PLOS One. 2013;8:e58824.

8. CEPAGRI. Centro de Pesquisas Metereológicas e Climáticas Aplicadas à Agricultura Informações sobre o clima. [cited 2013 Jan 15]. Available from: http://www.cpa. unicamp.br/outras-informacoes/clima_muni_572.html

9. Colosimo EA, Giolo SR. Análise de sobrevivência aplicada. São Paulo: Edgard Blucher; 2006

10. Costa FS, Silva JJ, Souza CM, Mendes J. Dinâmica populacional de Aedes Aegypti em área urbana de alta incidência de dengue. Rev Soc Bras Med Trop. 2008;41:309-12.

11. CVE. Centro de Vigilância Epidemiológica. Dengue dados estatísticos. São Paulo: CVE Secretaria de Estado da Saúde do Estado de São Paulo; 2008. [cited 2013 Jan 28] Available from: http://www.cve.saude.sp.gov.br/htm/zoo/Den_dir06.htm

12. Farnesi LC, Martins AJ, Valle D, Rezende GL. Embryonic development of Aedes aegypti (Diptera:Culicidae): influence of different constant temperatures. Mem Inst Oswaldo Cruz. 2009; 104:124-6.

13. Focks DA, Haile DG, Daniels E, Mount GA. Dynamic life table model for Aedes aegypti (Diptera:Culicidae): analysis of the literature and model development. J Med Entomol. 1993;30:1003-17.

14. Forattini OP. Entomologia médica. São Paulo: Edusp; 1965. v. 2

15. Franco O. Historia da febre amarela no Brasil. Rio de Janeiro: Ministério da Saúde/ Departamento Nacional de Endemias Rurais; 1969.

16. Gadelha DP, Toda AT. Biologia e comportamento do Aedes aegypti. Rev Bras Malariol Doenças Trop. 1985;37:29-36.

17. Gama RA, Alves KC, Martins RF, Eiras AE, Resende MC. Efeito da densidade larval no tamanho de adultos de Aedes Aegyti criados em condições de laboratório. Rev Soc Bras Med Trop. 2005;38:64-6.

18. Lambrechts L, Paaijmans KP, Fansiri T, Carrington LB, Kramer LD, Thomas MB, et al. Impact of daily temperature fluctuations on dengue virus transmission by Aedes aegypti. Proc Natl Acad Sci USA. 2011;108:7460-5.

19. Maciel-de-Freitas R, Marques WAM, Peres RC, Cunha SP, Lourenço de Oliveira R. Variation in Aedes aegypti (Diptera: Culicidae) container productivity in a slum and a suburban district of Rio de Janeiro during dry and wet seasons. Mem Inst Oswaldo Cruz. 2007;102:489-96.

20. Monteiro LCC, Souza JRB, Albuquerque CM. Eclosion rate, development and survivorship of Aedes albopictus (Skuse) (Diptera:Culicidae) under different water temperatures. Neotrop Entomol. 2007;36:966-71.

21. Pan American Health Organization. Epidemiological alert: update on dengue situation in the Americas. [cited 2014 March 18]. Available from: http://www2.paho.org/hq/ dmdocuments/2011/epi_alerts_March_18_2011_dengue_update1.pdf

22. Siegel S, Castellan NJ Jr. Nonparametric statisticss for the behavioral sciences. $2^{\text {nd }} e d$. New York: McGraw-Hill Book Company; 1988. 
LOPES, T.F.; HOLCMAN, M.M.; BARBOSA, G.L.; DOMINGOS, M.F. \& BARREIROS, R.M.O.V. - Laboratory evaluation of the development of Aedes aegypti in two seasons: influence of different places and different densities. Rev. Inst. Med. Trop. Sao Paulo, 56(5): 369-74, 2014.

23. Silveira Neto S, Nakano O, Barbin D, Villa Nova N. Manual de ecologia dos insetos. São Paulo: Agronômica Ceres; 1976.

24. Tauil PL. Aspectos críticos do controle do dengue no Brasil. Cad Saúde Pública. 2002;18:867-71.

25. Teixeira MG, Costa MCN, Barreto F, Barreto ML. Dengue: twenty-five years since reemergence in Brazil. Cad Saúde Pública. 2009;25(Suppl 1):S7-S18.

26. Tun-Lin W, Burkot TR, Kay BH. Effects of temperature and larval diet on development rates and survival of the dengue vector Aedes aegypti in north Queensland, Australia. Med Vet Entomol. 2000;14:31-7.
27. Walch RK, Facchinelli L, Ramsey JM, Bond JG, Gould F. Assessing the impact of density on field population of Aedes aegypti. J Vector Ecol. 2011;36: 300-7.

28. World Health Organization. Dengue and severe dengue. 2014. Fact sheet $n^{\circ} 117$. [cited 2014 March 18]. Available from: http://www.who.int/mediacentre/factsheets/fs117/ en/

29. Yang HM, Macoris MLG, Galvani KC, Andrighetti MTM, Wanderley DMV. Assessing the effects of temperature on the population of Aedes aegypti, the vector of dengue. Epidemiol Infect. 2009;137:1188-202.

Received: 13 May 2013

Accepted: 18 March 2014 